\title{
ABSURDITAS DALAM DRAMA LES MOUCHES KARYA JEAN-PAUL SARTRE Sebuah Pendekatan Semiotik
}

\author{
Oleh: \\ Birul Sinari Adi \\ Universitas Gadjah Mada (UGM), Yogyakarta \\ sinariadi@gmail.com
}

\begin{abstract}
This study is an attempt to assess absurdity in Les Mouches as a concept of pessimistic humanism. Regarding the issues expressed through the work may be understood on the humanism perspective, then, the aims to be achieved through this research is the understanding of the humanity issues, which have a great extent of possibilities expressed through the literary work. The drama play of Les Mouches is actually the manifestation of the problems of the human life, which deal with many possibilities as well. As a text, Les Mouches is a structure that arranges its constituent elements to create meaning. And within its function, Les Mouches, as a social and cultural phenomenon, is a communication act. This means that a literary work is a sign, and through this sign the literary work may be the expression thrusting concrete and fictitious experiences of the entire human life.
\end{abstract}

\begin{abstract}
Abstrak
Dalam penelitian ini, peneliti berupaya menilai absurditas dalam Les Mouches sebagai suatu konsep humanisme pesimis. Oleh karena persoalan-persoalan yang muncul pada karya dipahami sebagai persoalan kemanusiaan, maka tujuan yang ingin dicapai dengan penelitian ini adalah pemahaman persoalan kemanusiaan yang penuh kemungkinan-kemungkinan yang tertuang lewat bentuk karya sastra. Lakon drama Les Mouches sebenarnya merupakan wujud gambaran dari persoalan kehidupan manusia itu sendiri yang penuh dengan kemungkinan-kemungkinan. Pada tataran teks, Les Mouches merupakan suatu struktur yang hubungan unsur-unsurnya membentuk suatu pemaknaan, dan dalam fungsi sebagai gejala kemasyarakatan dan kebudayaan merupakan suatu tindak komunikasi. Artinya sastra sebagai tanda, dan lewat tanda ini karya sastra menjadi suatu pengungkapan yang menyodorkan pengalaman-pengalaman kongkrit dan fiktif seluruh kehidupan manusia.
\end{abstract}

Kata kunci: Abdsurditas, Les Mouches, Jean-Paul Sartre

\section{PENDAHULUAN}

\subsection{Latar belakang}

Ketika Perang Dunia II berlangsung pada dasawarsa 40-an, Prancis berada di bawah pendudukan Jerman. Keadaan tersebut rupanya tidak turut mematikan kreativitas para penulis lakon yang hidup pada masa itu. Mereka adalah orang-orang yang konsekuen dengan kesenimanannya. Hal ini terbukti dengan tetap ditulisnya lakon-lakon drama, bahkan dengan pementasannya (Jean Duvignaud dan Jean Lagoutte, 1974: 13).

Mereka yang ada di balik lakon-lakon drama itu adalah orang-orang yang mengalami sendiri situasi peperangan, serta kekejaman-kekejaman 
selama pendudukan. Mereka lalu menjadi saksi zaman dan menyuarakan aspirasinya. Para penulis lakon itu dihadapkan, dikejutkan oleh situasi masa itu, dan mencoba memahami dunia yang telah menjadi kacau. Maka tidak aneh jika lakonlakon drama yang mereka hasilkan lantas mengungkapkan atau menyimbolkan situasi masa itu. Lakon-lakon mereka dianggap banyak menyajikan refleksi kehidupan manusia yang absurd. Bahkan kata absurd sebagai suatu konsep kepekaan berkesenian dianggap sebagai "aliran" yang pantas disandang oleh lakon-lakon drama maupun oleh para penulis lakon pascaperang.

Pada saat yang bersamaan, di Prancis sedang berkembang dengan pesat suatu aliran filsafat, yaitu eksistensialisme. Aliran yang segera menjadi mode ini, bahkan juga merambah ke dunia sastra (Thomas Bishop, 1975: 7). Dalam filsafat ini, khususnya aliran eksistensialisme ateis, Jean-Paul Sartre dianggap sebagai tokohnya terutama di negara Prancis. Ia turut berperan sehingga eksistensialisme menjadi berkembang luas, dengan menyampaikan filsafat lewat karya sastra maupun tulisan-tulisannya. (A. Lagarde dan L. Michard, 1973: 601)

Kecenderungan yang ditampilkan oleh karyakarya sastra pada waktu itu juga tidak lepas dari adanya pertemuan dengan pemikiran Sartre. Karya-karya tadi yang disebut sebagai karya eksistensial, mempunyai kecenderungan untuk menampilkan keberadaan manusia yang dirasa absurd dan tragis. Hal ini sebenarnya menyiratkan suatu sikap yang pesimis terhadap kondisi manusia itu sendiri. Dalam pandangan eksistensialisme yang merasuk dalam sastra berpijak dari landasan bahwa Tuhan telah mati, dan melihat dunia maupun sejarah sebagai ketakjelasan dan absurd. Oleh karena itu melalui kecemasan para manusia, memainkan kebebasan mereka serta menolak kepalsuan yang ditawarkan oleh para rasionalis optimis, dibangun suatu humanisme baru dengan mencari gairah balik keputusasaan yang jelas dihadapi oleh para manusia (P.H. Simon, 1957: 176). Dalam pandangan eksistensial yang pesimis, tindakan-tindakan yang menunjukkan eksistensi selalu mengarah pada penyuaraan akan kecemasan manusia dan kekacauan zaman yang dihadapi.

Di sisi lain, Sartre juga mengalami situasi zamannya, merasakan masa pendudukan dan peperangan. Ia turut pula menjadi saksi bahkan melibatkan diri dengan zamannya. Hal ini men- jadikan sebagian besar karyanya lantas menyentuh, baik langsung maupun tidak, pada persoalan-persoalan manusia modern dalam segala kondisinya (Thomas Bishop, 1975: 7).

Eksistensialisme serta kompleksitas situasi kehidupan masa itu lantas terjabarkan lewat roman maupun lakon-lakon drama Sartre. Maka tokoh-tokoh yang tampil dalam karya Sartre tidak terlepas dengan situasi yang melingkupi diri mereka. Meski demikian, lewat karya sastra tersebut Sartre tidak sekedar menyodorkan pemikiran filsafatnya yang rumit, Sartre menguraikannya dalam bentuk-bentuk situasi yang sederhana. Hal ini dimaksudkan agar pergulatan para tokoh di dalamnya mudah dimengerti dan diidentifikasi (Thomas Bishop, 1975: 7). Dalam usahanya ini, Sartre dianggap lebih berhasil menguraikan gagasan-gagasan filsafatnya lewat lakon-lakon drama dari pada lewat roman-romannya.

Salah satu karya Sartre yang tertuangkan ke bentuk lakon drama, dan dianggap mewakili pemikirannya seperti yang diuraikan di atas, adalah Les Mouches. Lakon yang turut menentukan langkah Sartre dalam penulisan lakon drama selanjutnya ini, ditulis pada tahun 19411942 dan diterbitkan serta pertama kali dipentaskan pada tahun 1943, yaitu pada masa masih berkecamuknya suasana peperangan dan pendudukan (Thomas Bishop, 1975: 7).

Dari kenyataan latar sejarah yang diungkap, sebagai kondisi yang melingkupi para penulis lakon maupun karya-karya ciptaannya, menandai bahwa lakon-lakon drama Yang ditulis pada masa itu dianggap banyak yang menyuarakan tentang absurditas kehidupan manusia. Sebagai lakon drama yang muncul pada masa yang sama, anggapan ini mau tidak mau turut disandang oleh Les Mouches karya Sartre.

Les Muches sendiri adalah sastra lakon yang menggunakan mitos Yunani sebagai dasar ceritanya. Walaupun diilhami dari cerita kuno, lakon tersebut membawakan persoalan-persoalan aktual manusia moderen. Penggunaan mitos, yang merupakan bentuk cerita yang telah dikenal secara umum, sejalan dengan usaha Sartre menyodorkan pemikirannya lewat karya sastra khususnya dalam sastra lakon - yaitu memberi gambaran yang mudah dipahami. Hal ini sejalan dengan persoalan-persoalan yang disodorkan lewat lakon, yaitu ujud gambaran kompleksitas kehidapan manusia modern itu sendiri (Jean- 
Paul Sartre, 1973: 61). Upaya mengangkat mitos ke dalam lakon ini sendiri bukan diawali oleh Sartre atau para penulis lakon yang sezaman dengannya, tetapi pernah pula dilakukan oleh penulis lakon sebelumnya.

Mitos yang mendasari lakon Les Mouches, yaitu cerita tentang Oreste dan Glectre, telah pula ditulis oleh Giraudoux dalam bentuk drama dengan judul Electre. (Jean Giraudoux, 1972: 12). Kalau dalam lakon Giraudoux, Electre muncul sebagai tokoh yang memegang peranan, lakon drama Les Mouches milik Sartre ini lebih menampilkan Oreste sebagai tokoh. Meskipun begitu ketokohan Oreste dalam drama ini bukan semacam tokoh yang dilahirkan sebagai hero, yang merupakan takdir dan yang akan menentukan peranan atas dirinya (Lagarde dan Michard, 1973: 601).

Sebaliknya ia tidak ditentukan oleh takdir dan peranannya ditentukan oleh pilihannya sendiri, terealisasikan dengan tindakan langsung. Dengan kata lain Oreste adalah tokoh yang bebas, atas dirinya sendiri maupun dengan lingkungannya, namun dengan adanya kebebasan justru mengharuskan adanya tindakan yang akan memberi arti pada kebebasan itu sendiri maupun kepada pelakunya (Christian Descamps, 1973: 226). Ketika Oreste akhirnya membunuh ibunya sendiri serta pembunuh ayahnya. Perbuatan itu menjadi simbol suatu tanggung jawab dan legitimitas suatu tindakan. Dalam hal ini tindakan Oreste merupakan hasil pilihan dan tanggung jawabnya, dan tidak bisa disejajarkan dengan nilai-nilai baik dan buruk seperti yang dipahami secara umum (Lagarde dan Michard, 1973: 607).

\subsection{Landasan Teori}

Setiap pembaca karya sastra berhak memberikan penilaian tertentu pada suatu karya yang dibacanya. Hal ini berkaitan dengan sifat sastra itu sendiri, yaitu multitafsir, sehingga suatu karya sastra yang sama bisa mendapatkan penilaian berbeda dari pembaca yang berbeda pula. Namun dalam suatu penelitian ilmiah yang dituntut validitas serta pertanggungjawaban, untuk memberikan penilaian terhadap suatu karya sastra yang dianalisis perlu adanya suatu teori sebagai pendukung. Meskipun begitu, pemilihan terhadap teori yang digunakannya ini sepenuhnya ada pada pihak peneliti dengan melihat seluruh fenomena pada karya yang akan di- analisisnya.

Sementara upaya pemahaman karya sastra disadari tidak terlepas dari adanya pertalian pengarang dengan lingkungannya. Pertalian itu bisa dibaca sebagai tanggapan pengarang terhadap persoalan-persoalan yang terjadi dan dialaminya. Kondisi ini memang bisa terjadi secara timbal-balik, yaitu kondisi berpengaruh terhadap pandangan dari penanggapnya atau pemikiran dari si pengarang atas kondisi yang terjadi. Dan semua itu bisa jadi lantas termanifestasikan dalam karya. Dalam hal ini, karya sastra dari pengarang bisa menunjukkan semua itu dan studi objektif terhadap karya memang bisa membantu. Namun studi yang hanya mementingkan unsur-unsur intrinsik karya ini, dalam hal tertentu kurang bisa memasukkan persoalan yang ada dalam karya dengan aspek-aspek lain yang ada di luarnya.

Merujuk pada persoalan ini, maka dalam penelitian ini penggunaan pendekatan semiotik lebih ditekankan, namun tanpa mengabaikan kenyataan bahwa karya sastra juga merupakan suatu sistem yang mandiri. Sebab dengan pendekatan semiotik ini, yang sebenarnya memiliki dasar yang sama dengan pendekatan objektif, akan lebih memungkinkan menghubungkan karya dengan sistem tanda di luarnya. (Umar Yunus, 1981: 18) Dengan begitu, pendekatan semiotik lebih memungkinkan untuk memahami persoalan dalam karya sastra dengan lebih luas. Dan selain memungkinkan menghubungkan sistem suatu karya sastra dengan sistem dalam kehidupan, yang berarti menempatkan karya pada kedudukannya, sekaligus merupakan suatu pengakuan bahwa sastra bertolak dari kehidupan itu sendiri. (Genevieve, 1984: 2127)

\subsection{Metode Pengumpulan dan Analisis Data}

Penelitian ini menggunakan data utama yang diambil dari teks pokok yang dibahas, yaitu drama Les Mouches, yang lantas dipahami sebagai struktur makna. Pemahaman ini dimaksudkan sebagai pendekatan karya secara objektif, sekaligus sebagai penjabaran data utama dalam bentuk bentuk makna.

Langkah ini ditempuh secara langsung lewat proses pembacaan dan pencatatan. Pada tataran ini, hasil yang didapat dipahami sebagai kesatuan lewat suatu relasi, dan lantas dijalin dengan seloruh fenomena yang melingkupi data utama. 
Karena itu situasi kebebasan yang melingkupi tokohnya, sertatindakan-tindakan yang diambil atas adanya pilihan-pilihan dan konsekuensinya dianggap sebagai jalinan persoalan, sekaligus merupakan titik pusat pembicaraan yang diarahkan pada ancangan pemaknaan absurditas.

Hal ini dengan sendirinya mengandaikan adanya suatu pertalian yang memberi makna adanya eksistensi tokoh dalam kompleksitas dan realitas totalnya. Semua itu mengantar pembahasan melalui cara interpretasi yang mendasarkan pada penerapan prinsip semiotik yang menghubungkan jalinan-jalinan persoalan dengan seluruh unsur-unsur yang berkaitan dan konsep-konsep yang melatarinya, sehingga akan mengantar pada pemaknaan absurditas dalam drama Les Mouches.

\section{PEMBAHASAN}

\subsection{Semiotik sebagai Pendekatan Sastra}

Ada suatu keyakinan pada para peneliti sastra bahwa pencapaian penelitian dan pemahaman secara ilmiah tidak akan berhasil tanpa mengikutsertakan aspek kemasyarakatannya, yaitu memandang karya sastra sebagai tindak komunikasi. Meski dalam hal ini sastra bisa dianggap sebagai komunikasi tidak biasa, karena memiliki banyak segi aneh dan luar biasa terutama bila dibandingkan dengan tindak komunikasi lainnya, untuk memahaminya tidak mungkin tanpa memperhatikan aspek komunikatifnya. Hal ini berarti dalam memahami suatu karya sastra harus mendekatinya sebagai tanda, (signe), atau sebagai gejala semiotik (Teeuw, 1988: 43).

Di dalam pendekatan semiotik ini, segala unsur yang ada dalam suatu karya sastra dilihat sebagai bagian dari suatu sistem tertentu. Karena suatu karya sastra disusun berdasarkan suatu sistem, sesuatu yang hidup dan tumbuh dalam suatu masyarakat akan tercermin di dalam karya sastra (Atar Semi, 1985: 45). Dengan demikian, karya sastra tidak lepas dari sistem kemasyarakatan itu sendiri. Selanjutnya pendekatan semiotik tidak hanya dapat menghubungkan sistem dalam karya itu sendiri. Setidaknya dengan pendekatan ini memungkinkan bagi peneliti untuk menghubungkan sistem pada suatu karya sastra dengan sistem dalam kehidupan.

Pendeknya, semiotik adalah ilmu yang mempelaJarh tentang sistem tanda (Pierre Guiraud,
1971: 5). Ilmu ini menganggap seluruh fenomena sosial atau masyarakat dan kebudayaan sebagai tanda. Di sini Semiotik mempelajari seluruh sistem atau aturan-aturan yang memungkinkan tanda-tanda tersebut mempunyai arti. Sementara sastra sebagai sistem tanda, dilihat Teeuw (1988: 143), merupakan yang paling menarik dan kompleks, karena sastra sendiri merupakan eksplorasi dan perenungan terus-menerus tentang pemberian makna dengan segala bentuknya, penafsiran pengalaman, maupun koiraentar mengenai keberlakuan berbagai cara menafsirkan pengalaman.

Karena itu, bagi Guller (Teeuw, 1988: 143) tugas semiotik bukan hanya pendeskripsian tanda-tanda tertentu, melainkan memerikan konvensi-konvensi yang melandasi ragam perilaku dan seluruh pembayangan yang ada, dan mencoba menemukan konvensi-konvensi yang memungkinkan adanya makna atau berusaha mencari ciri-ciri kode yang menjadikan berlangsungnya komunikasi sastra. Demikian pula bagi setiap peneliti sastra harus menganalisis sistem tanda dan menentukan konvensi-konvensi yang memungkinkan tanda-tanda atau struktur tanda-tanda di dalamnya itu mempunyai makna (Rahmat Djoko Pradopo, 1995: 122).

\subsection{Sartre dan Dramanya}

Ketenaran Sartre, baik sebagai sastrawan maupun filosof sudah tidak diragukan lagi. Hal ini disebabkan oleh sepak terjang dan pengaruhnya di dua bidang tersebut. Berkaitan dengan itu, banyak buku atau tulisan-tulisan yang membicarakan karya-karya sastranya maupun tulisan-tulisan filsafatnya. Pada umumnya pembicaraan itu memberi kaitan yang jelas antara pemikiran Sartre dalam bidang sastra dengan filsafat. Seperti diketahui, Sartre sendiri berupaya membeberkan pemikiran-pemikirannya lewat karya sastra selain lewat tulisan-tulisan filsafatnya yang bernada ilmiah.

William Barrett yang menilai Les Mouches dan Huis C1os sebagai lakon drama Sartre yang terbaik menyatakan bahwa Oreste - tokoh dalam Les Mouches adalah corong bagi pandangan kebebasan Sartre (William Barrett, 1964: 567). Pendapat yang hampir senada menyatakan bahwa lakon Les Mouches merupakan ilustrasi pandangan Sartre tentang Tuhan, yaitu ketika manusia berhadapan dengan Tuhan maka bagi manusia hanya ada dua kemungkinan: tunduk 
kepada-Nya dengan menjadi objek belaka, atau memberontak (Bertens, 1985: 324).

Membicarakan Sartre tampaknya akan sulit dipisahkan dengan sastra lakonnya. Ketenaran serta banyaknya perhatian terhadap pemikiranpemikiran yang dilontarkannya, tidak bisa dilepaskan dari peranan serta dukungan lakonlakonnya. Kondisi ini sebenarnya mudah dimenge'rti, selain menunjukkan kegemilangannya sebagai sastrawan tepatnya penulis naskah lakon, lakon-lakon tersebut memang lebih mudah dipahami bila dibandingkan dengan karya filsafatnya. Karena itu pula naskah lakonnya cukup mendapat tanggapan serta perhatian dan terutama dapat pula diterima oleh khalayak luas. Di sisi lain, pemikiran-pemikiran kefilsafatan Sartre masih dapat terbaca dengan jelas dalam lakon dramanya, karena tergambarkan lewat bentuk-bentuk lebih nyata. Pendek kata, lewat lakon drama, pemikiran-pemikiran Sartre yang abstrak termanifestasikan ke dalam bentuk yang lebih kongkrit.

Berdasar fakta yang sangat menarik di atas, maka pada bagian ini dimaksudkan untuk membicarakan diri pengarang dengan lakon-lakan dramanya, dalam hal ini yang dimaksud adalah pemikiran-pemikiran atau konsep-konsep yang menjadi dasar lakon-lakon tersebut. Namun perlu disadari bahwa hal ini tidak dimaksudkan untuk menggulirkan pemahaman bahwa lakonlakon Sartre (1973: 56) sekedar sebagai lakon filosofis. Kondisi tersebut lebih dianggap sebagai fenomena literer, bahwasanya karya sastra sebagai ciptaan pengarang tidak terpisahkan dengan persoalan-persoalan kemanusiaan itu sendiri, yang secara langsung memang dihadapi oleh pengarangnya. Pendeknya hal ini dipahami sebagai pemikiran pengarang yang telah menempat dan mendapatkan bentuknya yang utuh dalam naskah lakon.

Sebagai perbandingan, Albert Camus adalah sastrawan dan dirinya bukan seorang filosof, namun karya-karya sastranya dianggap menyuarakan tema-tema filosofis.

\subsection{Sartre sebagai Sastrawan dan Filosof}

Sartre merupakan tokoh yang cukup penting pada dasawarsa 40-an. Namanya sering disejajarkan dengara Voltaire atau Victor Hugo. Ketenarannya itu, setidaknya memang didukung oleh sepak terjangnya. Minatnya terhadap berbagai hal sangat besar dan aktivitasnya cukup bera- gam. Selain karya sastra dan filsafat, Sartre juga menulis kritik seni, skenario film dan juga tulisan-tulisan yang berupa kajian politis. Di samping itu, Sartre juga terjun dalam bidang jurnalistik dan penerbitan, bahkan sempat terlibat dalam politik praktis. Hanya saja, peranannya dalam bidang sastra dan filsafat bisa disebut yang yang paling menonjol, karena itu Sartre lebih dikenal sebagai sastrawan atau filosof.

Seiring dengan berakhirnya PD II, nama maupun pengaruh Sartre semakin dikenal dan meluas. Ia turut memberi warna tersendiri pada dunia kesusastraan dan peta pemikiran masa itu. Kiprahnya ini dianggap sebagai pemicu munculnya suatu aliran yang disebut eksistensialisme. Aliran tersebut begitu populernya, sehingga para sastrawan dan kaum intelektual, baik tua maupun muda, banyak yang mengidentifikasikan diri mereka dengan aliran eksistensialisme ini. Di tengah maraknya perkembangan eksistensialisme, mereka yang menyebut dirinya sebagai eksistensialis dianggap lebih condong sebagai sastrawan daripada sebagai filosof. Hal ini agaknya tidak menimpa diri Sartre. Konsistensinya sebagai sastrawan dan filosof tetap terjaga, dan selain karya sastra dan filsafatnya terus tercipta, dari pemikiran filsafatnya ia bahkan dianggap sebagai eksistensialis yang paling berbobot kadar intelektualitasnya bila dibanding dengan para eksistensialis lainnya (William Barett, 1964: 565). Nama dan pengaruhnya kemudian tidak hanya menggaung di kalangan cerdik pandai Prancis atau Eropa, tetapi juga terdengar di Amerika dan bahkan di seluruh penjuru dunia.

Peranan Sartre sebagai sastrawan dan filosof ini turut menegaskan dirinya sebagai gambaran sosok hasil sintesis antara jiwa artistik yang kental dengan intensitas pikiran yang jenial; suatu figur antara Spinoza dan Stendhal. Adanya kesan semacam itu memang sukar ditampik. Terlebih lagi bila dilihat dari bobot karya-karya sastra dan filsafat yang dihasilkan. Namun, dengan sekedar menyebut adanya bakat suatu istilah yang sebenarnya kurang disukai oleh Sartre, tampaknya terlalu menyederhanakan dan juga berkesan naif. Penjelasan yang lebih memadai mungkin bisa diajukan, yaitu bahwa Sartre sebagai penulis tidak menginginkan dirinya berada dalam lingkup elitisme (Francois Ewald, 1991: 24). Artinya, ia tidak menulis dengan menggunakan bentuk penulisan tertentu, sebagai akibatnya mungkin hanya akan dimengerti oleh ka- 
langan tertentu pula. Sebaliknya, dengan menulis dalam berbagai bentuk pengungkapan, maka karya-karyanya dan dengan sendirinya pemikiran yang ada, mendapatkan pembaca yang lebih luas.

Hal itu rupanya telah disadari oleh Sartre. Terbukti sejak awalnya ia telah memilah-milah khalayak pembaca dalam kelompok-kelompok tertentu (Thomas Bishop, 1975: 12). Karyanya yang berupa kajian filsafat, semacam: L'imagination (1936), L "Etre et le Neant (1943), Critique de la raison dialectigue (1960), diperuntukkan bagi segolongan kecil intelektual yang mengkhususkan diri pada bidang filsafat. Karena itu dalam karya-karya tersebut digunakan bahasa dan penalaran yang bersifat teknis. Sedangkan karyanya yang berupa kritik sastra dan tulisan-tulisan politis, seperti: Saint Genet, Goniedien et ie Martyr. Les Gonuliunis tes et la paix (1952), L'Idiot de la fanille (1971-1972), diperuntukkan bagi para intelektual yang tidak mengkhususkan diri nada bidang filsafat. Sementara untuk mengungkapkan pemikiranpemikirannya pada khalayak yang lebih luas, ia menyampaikannya lewat roman dan lakon dramanya, semacam: La Nausee (1938), Les Mouches (1943) atau Huis Clos (1944).

\subsection{Sartre, Kesastraan dan Lakon-Lakon Dramanya}

Upaya penjadian karya sastra sebagai salah satu bentuk pengungkapan pemikiran selayaknya dipahami dalam konteks kesastraan Sartre. Hal ini mengingat karya sastra Sartre tidak kehilangan bobot kesastraan, dan memiliki bentuk pengucapan berbeda dengan teks-teks filsafat. Jelasnya, karya-karya sastra tersebut tidak secara langsung menempati fungsi sebagaimana yang diemban oleh teks-teks filsafat.

Namun hal itu sekaligus memberikan suatu pengertian yang pasti dari setiap karya sastra yang dihasilkannya, baik yang berupa naskah lakon ataupun roman, yaitu bahwa karya-karya sastra tersebut memang tidak sekedar dimaksudkan sebagai ajang penumpahan ekspresi diri atau sebagai ajang pemburuan atas kaidah-kaidah estetika kebahasaan semata, yang hanya berujung pada pencapaian indah kata atau bahasa.

Hal itu sebenarnya bukan hanya karena sebagai sastrawan Sartre juga seorang filosof, tetapi agaknya sudah menjadi semacam tradisi bagi pengarang-pengarang Prancis untuk selalu berangkat dengan konsep-konsep kesastraan yang kemudian menjadi dasar bagi karyakaryanya. Serdasarkan tradisi kepenulisannya, terlihat bahwa fakta atau alat cerita semacam plot, tokoh maupun gaya penceritaan bagi Sartre merupakan persoalan kedua. Sebelum itu, dirinya terlebih dahulu memilih subjek-subjek baku seperti kebebasan, kebetulan, tanggung jawab, dan sebagainya. Subjek-subjek tersebut dimaksudkan untuk mengisi aforisme-aforisme seperti: malapetaka manusia justru karena dirinya bebas, eksistensi bukan determinasi karena eksistensi berupa kebetulan, lari dari eksistensi masih tetap disebut eksistensi (Muslikh Madiyant, 1989: 36).

Sartre mempunyai pandangan bahwa pengarang tidak berbeda halnya dengan seorang pembicara. Hanya saja dalam pandangan itu pengarang merupakan seorang pembicara berbicara lewat karya-karyanya. Karya sastra di sini mempunyai arti sebagai sarana komunikasi bagi pengarangnya. Pengarang menghendaki agar apa yang diungkapkan lewat karyanya itu dapat tersampaikan pada pembaca. Agaknya Sartre sangat percaya akan kemampuan karya sastra sebagai sarana penyampai aspirasi pengarang. Begitu pula dalam karya-karya sastra itu terlihat bahwa Sartre merupakan seorang pembicara yang fasih.

Namun perlu disadari bahwa dengan ancangan semacam itu, Sartre tidak memaksudkan dirinya sebagai pengarang yang sekedar bertutur tentang pemikiran-pemikirannya. Artinya, karya sastranya masih berada dalam konteks kesastraan. Dan agar apa yang ditampilkan dalam karya sastra tersebut bisa dipahami, maka yang ditempuh tidak lain yaitu menampilkan karya sastra sebagai suatu kondisi yang benar-benar nyata. Pendeknya, menurut Sartre, pengarang harus menampilkan persoalan-persoalan aktual manusia, yaitu persoalan-persoalan yang dikenali oleh pembaca dengan akrab.

Sebagai pengarang, Sartre memang bermaksud membangun hubungan dialogis dengan pembaca. Dalam hal ini Sartre mempunyai keyakinan bahwa karya sastra mampu menjalin adanya komunikasi yang paling erat antara pengarang dengan pembacanya (Francois Ewald, 1994: 9). Keyakinan Sartre itu pun bukannya tanpa dasar. Dalam pandangannya karya sastra berada dalam tataran wacana. Di sini, karya 
merupakan sebentuk makna yang mengandung suatu pengertian atau merujuk pada hal tertentu pada suatu realitas dunia. Sebagaimana karya estetik lainnya, menurut Sartre objek karya sastra addlah realitas dunia, hanya saja realitas itu dihadirkan secara imajinatif dalam bentuk karya sastra (Sartre, 1948: 75).

Pada arti ini, realitas dunia yang disajikan secara imajinatif lewat karya sastra hadir untuk menunjukkan pada pembaca bagaimana seharusnya mereka menghadapi dan bertindak dalam realitas semacam itu. Pendeknya, karya sastra Sartre merupakan suatu sarana penyelamatan metafisis manusia atas dunianya (Michel Contat, 199: 38). Lewat karya sastra dibangun suatu konstruksi kebebasan, sekaligus menjadi padanan dari realitas dunia.

Dalam karya-karya sastranya tokoh-tokoh Sartre digambarkan berada dalam suatu dunia. Mereka dalam keadaan sendiri, tanpa tujuan pasti maupun determinasi-determinasi tertentu. Dalam kondisi demikian itu mesti menjadi manusia di antara manusia lainnya dengan harapan dapat menemukan arti dari keberadaan mereka yang sebelumnya bukanlah apa-apa. Dalam pandangan eksistensialisme, realitas dunia ini hanyalah kebetulan, dan absurd. Bagi Sartre penemuan kondisi absurd bukan dalam hubungan manusia dengan benda atau manusia dengan dunia, tetapi kondisi itu sendiri yang terjadi secara kebetulan (Claude-Edmonde Magny, 1971: 61)

Meski karya-karya Sartre di kemudian hari mengalani pergeseran, namun pada dasarnya karya-karya sastranya masih tetap berada dalam satu benang merah. Bisa dikatakan karya-karyanya masih menganut pola-pola sama. Karya sastra Sartre bisa dipahami sebagai susunan bentuk-bentuk yang menunjukkan dengan jelas kesukaran-kesukaran yang bakal dihadapi oleh kesadaran (Claude-Edmonde Magny, 1971: 61). Tokoh-tokoh Sartre justru menghadapi persoalan-persoalan ketika mereka sadar bahwa dirinya berada dalam suatu kondisi tertentu. Jelasnya, setiap munculnya kesadaran dari tokohnya, mengimplikasikan adanya konsekuensi-konsekuensi yang bisa mencelakakan.

Sejak tahun 1940, karya-karya sastra Sarte mulai meninggalkan tema-tetna kesendirian dan beralih pada solidaritas maupun keterlibatan manusia dalam sejarah. Karya-karya Sartre tidak lagi berbicara tentang keberadaan ma- nusia semata, yang tercerabut dan terpisahkan dari persoalan-persoalan sejarahnya, sebaliknya Sartre berusaha menggambarkan suatu konsep humanisme yang mengakar dan terlibat aktif dalam menghadapi kondisi zaman (Jacques Bersani, 1970: 26-27)

Dekade 40 -an itu bisa dibilang sebagai masa produktif Sartre sebagai seorang penulis lakon. Selama lima tahun, dari 1943-1948, ia menghasilkan lima naskah lakon: Les Muches (1943), Huis Clos (1944), Morts sans sepulture, La Putain respectueuse (1946), Les Mains Sales (1948). Menginjak tahun 50-an, intensitas Sartre dalam menulis lakon drama mulai berkurang. Akan tetapi tidak berarti ia berhenti sama sekali. Beberapa lakon dramanya masih muncul, bisa disebut di sini, yaitu Le Diable et Ie Bon Pieu (1951), Nakrassov (1955), Les sequestres d'Altona (1959), dan juga lakon-lakon adaptasi, Kean (1953) dari karya Alexandre Dumas, dan Les Troyennes (1965) dari Euripide.

Secara ringkas sebagian lakon-lakon itu akan dituturkan dalam uraian di bawah ini.

Dalam Huis Clos dikisahkan tentang berkumpulnya tiga orang yang telah "mati" dalam sebuah ruangan. Mereka adalah Joseph Garcin, seorang wartawan, Estelle Rigault yang berasal dari Paris, Ines Serano, seorang pegawai pos. Dalam situasi itu, mereka kemudian saling mengenal masa lalu masing-masing. Garcin pernah melakukan desersi dan kemudian dihukum tembak. Estelle yang sudah menikah dengan seorang lelaki tua tapi kaya, kemudian mempunyai kekasih lagi dan membunuh anak hasil hubungan gelap mereka itu. Ines merusak hubungan sepasang suami istri dengan cara merebut si suami. Ketiganya itu terlibat dalam hubungan rumit di mana masing-masing memandang yang lain sebagai objek diri mereka: "Neraka adalah orang lain".

Les Maine Sales berkisah tentang seorang komunis muda, yaitu Hugo Barines. Sebelumnya tokoh ini tidak mengenal apa yang disebut rasa lapar atau yang dinamakan kesulitan dalam hidup, karena dirinya selalu terlindung dari persoalan semacam itu. Namun dalam keadaan itu ia .iustru merasa tidak berarti. Karena itu ia menginginkan sesuatu hal yang dapat memberi arti pada hidupnya. Hal itu diwujudkannya dengan menerima tugas untuk membunuh Hoederer, seorang pemimpin partai, atas alasan politis. Ia kemudian berhasil membunuh meski saat itu 
lebih didasari oleh rasa cemburu. Sekeluarnya dari penjara Hugo lantas kembali menuntut arti dari tindakannya itu. Namun partainya telah memutuskan untuk tidak menerima dirinya kembali.

Lewat Le Diab1e et 1e Bon Dieu dikisahkan tentang seorang petualang bernama Goetz yang menjadi pemimpin pasukan perang. Dirinya adalah seorang yang melakukan kejahatan atas nama kejahatan. Ia kemudian berpaling pada kebaikan. Namun tampaknya tindakannya itu tetap tidak mendapat tanggapan dari Tuhan. Maka ia lantas memutuskan untuk berjalan pada pilihannya sendiri yaitu berpaling pada kepentingan manusia.

\subsection{Sartre dan Konsep Dramatiknya}

Dalam seluruh lakon-lakon Sartre hampir dapat dikatakan terdapat suatu kesamaan yang mendasar. Kesamaan yang dimaksud yaitu ditampilkannya tokoh-tokoh lakon sebagai manusia-manusia yang bebas. Dengan kata lain, lakon-lakon Sartre selalu menyuarakan kebebasan manusia. Dalam pandangan Sartre, kebebasan yang dimiliki manusia tersebut memiliki keterbatasan, sehingga bisa dikata manusia adalah makhluk bebas dalam keterbatasan. Yang menjadi pembatas atas kebebasan itu tidak lain yaitu situasi yang melingkupi diri manusia (Sartre, 1973: 58).

Pada dasarnya situasi-situasi semacam itu yang mewarnai dan ingin ditampilkan Sartre dalam lakon-lakonnya. Situasi itu dalam lakon Sartre muncul secara sederhana namun penuh dimensi kemanusiaan. Hal itu dimaksudkan untuk mewujudkan gambaran manusia yang terlibat dalam pilihan-pilihan bebas, saat-saat manusia sedang bertindak, dan saat-saat manusia harus melibatkan dirinya dengan suatu moral dan keseluruhan hidupnya (Francis Jeanson, 1955: 8).

Dalam penggambaran itu, lakon-lakon Sartre tidak berbicara tentang karakter-karakter psikologis manusia, semacam watak-watak pengecut, penipu, ambisius dan sebagainya. Sarte tidak membangun lakon-lakonnya dengan konflik-konflik karakter. Hal itu justru dengan segera digantikan dengan konflik-konflik hak. Pada pengertian ini konflik-konflik tadi menduduki tempat sebagai situasi sendiri.

Sartre memang tidak telrihat mengupayakan adanya pembaharuan dalam lakon-lakonnya, misalnya seperti yang dilakukan oleh Beckett atau Ionesco. Dalam hal ini apa yang dilakukan Sartre bisa disebut sebagai pemanfaatan tradisi. Ini terlihat dengan jelas dari upaya penempaan mitos-mitos Yunani sebagai pijakan ceritanya. Selain menggunakan mitos, dalam mewujudkan tokoh-tokohnya Sartre "meminjam" pengertianpengertian yang telah diajukan oleh Hegel dan Corneille. Dari Hegel itu kegairahan-kegairahan yang dimiliki manusia tidak semata sebagai cerminan dari sifat manusia, tetapi kegairahan itu sendiri dipandang sebagai hak. Dengan prinsip Corneille maka manusia dilihat dalam seluruh kompleksitas dan realitas totalnya.

Sebagai representasi dari pandangan semacam itu, akibatnya berpengaruh pula terhadap struktur penceritaan lakon-lakon Sartre. Lakonlakon Sartre biasanya memulai "permainannya" sejak dari awal. Alur bisa dikata terbangun dari puncak, karena dari mula konflik-konfliknya telah terbangun, dan hanya berbicara pada satu pusat peristiwa, dengan demikian tokoh-tokoh yang terlibat dalam cerita tidak begitu banyak. Cerita dalam lakon berlangsung dalam waktu yang pendek, kadang hanya berlangsung dalam beberapa jam saja. Kedatangan Greste ke Argos dengan saat Oreste membunuh Egisthe dan Clytemnestre hanya berselang beberapa waktu. Demikian pula dalam lakon Huis Clos, konflik dari tokoh-tokohnya berlangsung dalam intensitas waktu yang tidak jauh berbeda.

Tokoh-tokoh Sartre yang berada dalam situasi yang ditampilkan lewat lakon-lakon itu pada akhirnya mempunyai arti sebagai pembenaran dan sekaligus contoh yang fungsional untuk menunjukkan realitas kehidupan manusia itu sendiri. Hal ini ditempuh dengan cara menciptakan realitas lakon sebagai mitos, dengan jalan menyajikan pada publik suatu gambaran yang diperbesar dan diperkaya dengan kenistaan yang dialami oleh manusia sendiri.

\subsection{Ringkasan Cerita}

Oreste adalah anak dari Agamemnon dan Clytemnestre, penguasa di Argos. Sewaktu ia masih kecil sekitar tiga tahun usianya, ayahnya dibunuh oleh Egisthe, kekasih gelap Clytemnestre. Sejak saat itu pula, Egisthe berkuasa di Argos dan sekaligus menjadikan Clytemnestre sebagai istrinya. Egisthe juga memerintahkan agar Oreste dibunuh, namun Oreste dapat terlepas dari maut yang mengancam dan ia kemudian dipeli- 
hara oleh seorang borjuis kaya di Athena. Di pengasingan Oreste tumbuh sebagai pemuda terdidik, dengan didampingi seorang guru, ia belajar sekaligus mendapat pengajaran dan banyak pula membaca buku-buku. Bersama gurunya itu, Oreste sering mengadakan perjalanan, dalam rangka belajarnya, dari satu tempat ke tempat lain.

Kisah Les Mouches ini sendiri dimulai dengan kedatangan Oreste, yang menyamar sebagai Philebe pemuda dari Corinthe, bersama le Pedagogue, guru sekaligus pembantunya, ke Argos setelah hampir lima belas tahun ia meninggalkan kota kelahirannya itu. Sejak kedatanggannya, mereka merasa tidak mendapatkan sambutan yang menyenangkan dari para warganya, karena setiap orang yang mereka temui selalu menghindar dan lari ketakutan. Selain itu, kota Argos terlihat bagaikan kota mati, gersang dan dipenuhi oleh lalat-lalat yang juga mengerumuni seluruh penduduknya.

Mereka kemudian bertemu dengan Jupiter yang mengaku sebagai Demetrios dari Athena. Dari Jupiter ini Oreste mengetahui keadaan yang sedang berlangsung di Argos, tentang diri Egisthe, tentang warganya yang diliputi oleh rasa sesal, dan tentang lalat-lalat yang dikirim oleh para Dewa sebagai simbol bagi penyesalan seluruh warga Argos. Sedari mula, le Pedagogue telah menasehati Oreste agar mereka meninggalkan tempat itu, namun Oreste tidak menanggapinya. Jupiter juga memberi saran yang sama terhadap Oreste agar meninggalkan kota Argos, karena Oreste tidaklah berada dalam penyesalan maupun kejahatan warga Argos, sehingga dirinya terpisahkan ciengan mereka.

Ketika berada di hadapan istana ayahnya, tempat ayah dan dirinya dilahirkan sekaligus tempat ayahnya dibunuh, Oreste baru benarbenar menyadari bahwa tidak ada lagi kenangan padanya, seakan dirinya melihat istana itu untuk pertama kalinya. Le Pedagogue lantas mengingatkan Oreste akan ajaran-ajaran yang diberikan padanya bahwa dirinya bebas dari segala ikatan. Namun Creste merasa kebebasan yang dimilikinya itu menjadikan jiwanya terasa kosong, istana di hadapanya bukan lagi miliknya karena itu tidak ada yang dilakukannya. Maka ia lantas memutuskan untuk meninggalkan Argos. Meski begitu, Oreste mengandaikan adanya tindakan yang dapat memberinya hak perlu segera tetap untuk menjadi warga Argos, sekalipun tin- dakan ittu adalah membunuh ibu kandungnya sendiri.

Namun sebelum meninggalkan Argos, Oreste bertemu perempuan yang tetap tinggal dan Clytemnestre. Electre banyak diperlakukan sebagai budak yang keperluan ibu kandungnya itu ia menyimpan kebencian yang itu pula, Oreste bertemu dengan ibu kandungnya, Clytemnestre, yang sedang mencari Electre agar bersiap-siap untuk mengikuti pesta kematian yang akan segera berlangsung. Baik Clytemnestre maupun Electre tidak mengetahui bahwa pemuda di dekat mereka itu dan mengaku bernama Philebe sebenarnya adalah Oreste. Sementara itu, Electre yang awalnya menolak untuk hadir dalam pesta akhirnya memutuskan untuk datang, bahkan ia mengundang Oreste untuk ikut menyaksikannya.

Namun, ketika pesta yang diselenggarakan bagi orang-orang mati itu sedang berlangsung dan seluruh warga Argos yang berkumpul, termasuk Egisthe dan Clytemnestre, semua mengenakan baju berkabung yang berwarna hitam, Electre justru muncul dengan pakaian putih. Hal itu membuat Egisthe menjadi marah, apalagi Electre tetap menolak untuk melepas dan mengganti pakaiannya, bahkan ia berusaha mempengaruhi mereka yang hadir dalam upacara itu untuk tidak lagi memiliki rasa takut meski akhirnya usaha Electre tersebut gagal. Egisthe lantas mengusir Electre ke luar dari wilayah Argos dan memberi wewenang pada siapa pun yang bertemu untuk menyerangnya.

Mengetahui bahwa keselamatan Electre bakal terancam bila tetap berada di Argos, maka Oreste kemudian mengajaknya untuk segera melarikan diri bersama-sama. Namun ternyata Electre menolak ajakan itu karena ia memang tidak ingin meninggalkan Argos, baginya kejahatan hanya dapat dilawan dengan kejahatan pula dan dirinya menunggu kedatangan seseorang, yaitu saudara lelakinya, yang akan melaksanakan impiannya itu. Mendengar hal itu, Oreste akhirnya mengaku bahwa ia sebenarnya adalah saudara lelaki Electre, orang yang selama ini selalu ditunggunya. Tetapi Electre tidak langsung percaya dengan pengakuan Oreste itu. Maka Oreste berusaha meyakinkannya, mengatakan keadaan dirinya yang asing terhadap orang lain maupun bagi dirinya sendiri, karena itu ia menginginkan semua kenangannya, untuk berada di antara warga Argos dan, saat itu pula, 
Oreste bermaksud tidak akan meninggalkan tempat itu lagi.

Oreste bahkan memutuskan untuk membunuh Egisthe dan Clytentnestre dan meminta pada Electre agar mengantarkannya memasuki istana untuk melaksanakan niatnya itu. Meski diri Oreste, jauh dari yang dibayangkannya semula, akhirnya Electre mengakuinya sebagai saudara lelakinya karena tekad dan keputusan Oreste itu adalah apa yang selalu berada dalam impiannya. Maka mereka berdua lantas bersama-sama menuju ke istana.

Sementara itu, Jupiter berusaha memberitahu Egisthe akan datangnya bahaya yang mengancam bahwa Oreste dan Electre telah bertekad untuk membunuhnya. Akan tetapi, Egisthe rupanya tidak menanggapi peringatan itu karena ia merasa lelah, dirinya ternyata selama ini hanya menjalani "jalan" yang telah ditentukan. Akhirnya Oreste berhasil membunuh Egisthe dan, bahkan, sekaligus Clytemnestre. Meski sesaat Electre merasa gembira dengan terbunuhnya Egisthe, namun sebenarnya ia merasa ragu saat Oreste juga membunuh Clytemnestre, ibu kandung mereka sendiri. Setelah pembunuhan itu, mereka lantas pergi ke candi Apollo, menghindar dari lalat-lalat yang mulai mengerumuni dan juga dari kejaran para penjaga istana.

Di dalam candi tersebut, Oreste dan Electre tertidur. Ketika bangun Electre merasakan dirinya menjadi tua hanya dalam semalam. Dan para Erinnye - dewi-dewi penyesalan - yang berkerumun mulai mengganggu dan mempengaruhinya bahwa Oreste sebenarnya hanya menjerumuskan diri ke dalam tindakan keji. Akan tetapi, Oreste berusaha menginggatkan Electre akan impian-impiannya dan para Erinnye itu bermaksud memisahkan diri mereka.

Electre yang mulai terpengaruh justru berbalik mulai membenci saudara lelakinya itu. Ketika itu Jupiter datang menawarkan bantuan pada Oreste dan Electre dengan syarat mereka berdua bertobat dan menyesali dosa-dasa mereka serta tunduk padanya. Jupiter juga mengingatkan bahwa di luar seluruh warga Argos yang marah sedang menunggu, siap untuk merajam mereka. Electre yang telah terbujuk lantas menyerahkan diri pada Jupiter dan meninggalkan Oreste sendirian. Sedangkan Oreste tetap bertahan pada pilihannya dan bertekad menjadi raja tanpa wilayah, tanpa rakyat. Maka, dihadapan seluruh warga Argos Oreste berkata bahwa ia akan pergi dengan membawa semua lalat dari kota itu agar warganya terbebas dari rasa sesal dan dosa. Oreste kemudian ke luar meninggalkan candi Apollo, dan, bersamaan dengan itu, para Erinnye pun dengan sigap langsung menerkam dirinya.

\section{PENUTUP}

Dengan analisis yang memanfaatkan semiotik sebagai pendekatannya, sampailah penelitian ini pada hasil-hasilnya yang terangkum dalam suatu kesimpulan. Pemberian Les Mouches sebagai lakon yang menyajikan wujud realitas kondisi manusia telah mengungkap gambaran manusia dalam dunia beserta seluruh kompleksitas dan realitas yang harus dihadapi. Gambaran itu tidak lain merupakan suatu bentuk pengucapan bahwa manusia berada dalam penjara kenyataan dunia, terperangkap di dalamnya tanpa mampu menghindarkan.

Dalam Les Mouches, penjara kenyataan itu telah merangkap Oreste dalam sebuah dunia yang bernama Argos. Kondisi yang serba menyedia, terberi sekaligus kebetulan itu memberi suatu pengertian bahwa ada dalam dunia adalah absurd. Hal itu sekaligus menandai keberadaan manusia dalam ruang dan waktu, disini dan sekarang. Dalam hal ini Oreste merupakan gambaran manusia semacam itu, dan kemunculan di Argos sebagai manusia menyajikan suatu pengertian bahwa keberadaannya itu bukan determinasi. Sebab, pada saat itu Oreste tidak lagi memiliki kaitan dengan masa lalu, dan masa depan sepenuhnya ada ditangannya.

Kondisi itu mengantarkan manusia pada suatu kegamangan. Kegamangan itu disini dimunculkan sebagai kesadaran Oreste bahwa eksistensi semata-mata bergantung padanya, ia sendirilah satu-satunya sumber segala nilai dan makna. Kesadaran yang dimaksud itu didukung oleh kenyataan keberadaan dirinya yang ada bersama-sama dengan manusia lainnya. Selanjutnya, keberadaan suatu kenyataan yang memang tidak bisa dihindari. Tepatnya, Oreste menghadapi semua itu sebagai bagian dari keberadaannya dalam dunia.

Dan hal itu, sebagai realitas ruang dan waktu yang diterima, menjadi pijakan bagi manusia untuk memberi makna pada ke-mengada-annya, membentuk citra diri sebagai manusia dalam dunia. Keterlibatan Oreste dalam dunia berna- 
ma Argos itu direalisasikan dengan suatu tindakan: membunuh Egisthe dan Clytemnestre. Tindakan itu sendiri dengan demikian dapat dikatakan sebagai upaya pemberian makna itu sendiri. Suatu upaya yang harus diusahakan dan dilakukan oleh manusia dalam dunia dengan berbuat sesuatu, bisa jadi menyenangkan atau pun tidak.

Maka, Les Mouches sebagai perwujudan realitas kondisi manusia yang ada dalam dunia, sekaligus seabgai dunia itu sendiri telah menyajikan suatu humanisme lewat diri Oreste sebagai tokohnya. Namun agaknya hal itu digambarkan dengan pesimis. Keterlemparan Oreste dalam dunia yang telah ada dan menyedia mempertemukannya dengan manusia lain. Hal itu selanjutnya muncul sebagai konflik hak. Konflik itu terbangun dari relasi keberadaan mereka dalam dunia, yaitu Argos. Oreste yang dulunya adalah warga Argos dan sekarang berada di situ bukan lagi sebagai warga berhadapan dengan manusia-manusia lain yang tidak lain adalah para warga Argos. Konflik itu sekaligus merupakan konflik subjek-objek. Oreste lewat diri Electre membangun relasi konflik itu dengan penguasa Argos yang telah memisahkannya dengan kota itu, yaitu Egisthe dan Clytemnestre. Pembunuhan yang dilakukan Oreste terhadap Egisthe dan Clytemnestre dapat dipahami dalam arti ini. Kedatangan Oreste sebagai subjek telah menjadikan manusia lain, disini Egisthe dan Clytemnestre sebagai objek. Padahal manusia tidak bisa menjadi objek tanpa kehilangan kemanusiaannya. Dengan kata lain, manusia hanya dapat menjadi objek bila dalam kematian.

Hal itu juga terbangun dalam relasi Oreste dengan warga Argos. Tindakan Oreste dengan membunuh Egisthe dan Clytemnestre tidak menghapus relasi subjek-objek antara dirinya dengan warga Argos. Maka ketika Oreste meninggalkan Argos bukanlah berarti ia telah memilih menjadi objek dengan menjadikan warga Argos seabgai subjek. Oreste tetaplah menjadi subjek untuk dirinya. Hubungan ini leawt Les Mouches agaknya ingin digambarkan selalu mewarnai hubungan antar manusia.•

\section{DAFTAR PUSTAKA}

Barret, William, 1964, "Sartre" On contemporary Literature, (ed). Richard Kostelanetz, New York: Avon Book.

Barthes, Roland, 1957, Mythologies, Paris: Editions du Seuil.

Bersani, Jacques, et.al., 1970, La Litterature en Frace Depuis 1945, Paris: Bordas.

Bertens, K. 1985., Filsafat Barat Abad XX Jilid II, Jakarta: PT. Gramedia. 1987, (ed), Fenomenologi Eksistensial, Jakarta: PT. Gramedia.

Bishop, Thomas., 1975, Huis Clos, Paris : Lire Aujourd'hui, Hachette.

Bouty, M., 1991, Kamus Karya Sastra Perancis. Terj. Mardiani Bahasoan, Jakarta: AMP Publications. Contat, Michel., 1991, “Le Roman Existentiel”, Magazine Litteraire No. 293, Novembre.

Damono, Supardi Djoko, 1984, Sosiologi Sastra: Sebuah Pengantar Ringkas, Jakarta: Pusat Pembinaan dan Pengembangan Bahasa Departemen Pendidikan dan Kebudayaan.

Deleuze, Gilles, 1966, "Structuralisme", Histoire de la Philosophie de XXe siècle. Paris: Hachette.

Descamps, Christian, 1973, "Les Existentialisme", Histoire de la Philosophie de XX siècle. Paris: Hachette.

Duvignaud, Jean et Jean Lagoutte, 1974, Le Theatre Contemporain. Paris: Librairie Larousse. 1974.

Elsom, John, 1963, "Genet and the Sadistic Society", The London Magazine. Vol. 3 No. 5, August.

Ewald, Francois, 1991, "Le Continent Sartre”, Magazine Litteraire. No. 293, Novembre.

"Une Philosophie Pour Notre Temps", Magazine Litteraire No. 320, Avril.

Fokkema, D.W. and Elrud Kunne-Ibsch, 1977, Theories of Literature in the Twentieth Century, London: C. Hurst and Co.

Genevieve, Idt., 1984, “Sartre”, Dictionnaire de Litteratures de Langue Francais. Paris: Bordas.

Giraudoux, Jean,1972, Electre. Paris: Le Livre de Poche. Texte integral.

Guiraud, Pierre, 1971, La Semiologie. Paris: Presses Universitaires de France. 
Jeanson, Francis, 1955, Sartre: Par lui-meme. Paris: Editions du Seuil. 1966, Sartre: Les ecrivains devant Dieu. Paris: Desclee de Brouwer.

1980, Sartre and the Problem of Morality, transl. Robert V. Stone, Bloomington: Indiana University Press.

Kartodirdjo, Sartono, 1959, Tjatatan tentang Segi-segi Messianistis Dalam Sedjarah Indonesia, Yogyakarta: Penerbitan Lustrum II, UGM.

Lagarde, A. et L. Michard, 1973, Les Grands Auteurs Francais, Paris: Bordas,.

Madiyant, Muslikh, 1989, Ateisme dalam Pendekatan Strukturalisme Metahistoris pada Teks-teks Sartre dan Mochtar Lubis, Skripsi Sarjana, Yogyakarta: Fakultas Sastra UGM.

Magny, Claude-Edmonde. Litterature et Critique. Paris : Payot, 1971.

Piaget, Jean. Le Strcuturalisme. Paris : Presses Universitaires de France. 1968.

Pradopo, Rakmat Djoko, 1995, Beberapa Teori Sastra, Metode Kritik dan Penerapannya, Yogyakarta: Pustaka Pelajar,.

Sartre, Jean-Paul, 1948, Qu'est-ce que La Litterature ?, Paris: Gallimard,. ,1973, “Forger des Mythes", Un Theatre de Situation, Paris: Gallimard. 1973, Huis Clos suivi de Les Mouches, Paris: Gallimard.

Semi, Atar. 1985, Kritik Sastra, Bandung: Angkasa.

Silitonga-Djojohadikusumo, Sukartini, 1984, Mitologi Yunani, Jakarta: Djambatan.

Simon, P.H., 1995, Histoire de Litterature Francaise Au XXe siècle. II. Paris: Librairie Armand Colin.

Teeuw, A., 1995, Membaca dan Menilai Sastra, Jakarta: PT. Gramedia. 1988, Sastra dan Ilmu Sastra, Jakarta: Pustaka Jaya Girimukti Pasaka.

Yunus, Umar, 1981, Mitos dan Komunikasi, Jakarta: Sinar Harapan, 1981. 